DOI

\title{
ПРОБЛЕМАТИКА МЕДИЧНОГО ТА ГОМЕОПАТИЧНОГО ДИСКУРСІВ У ВИКЛАДАННІ КУРСУ ЗА ВИБОРОМ “ГОМЕОПАТИЧНІ ЛІКАРСЬКІ ЗАСОБИ”
}

\author{
А. В. Курінний \\ Запорізький державний медичний університет

\begin{abstract}
THE ISSUES OF MEDICAL AND HOMEOPATHIC DISCOURSES IN TEACHING ELECTIVE COURSES “HOMEOPATHIC MEDICINES”
\end{abstract}

\author{
Zaporizhian State Medical University
}

A. V. Kurinnyi

\begin{abstract}
У статті розкривається досвід викладання курсу за вибором “Гомеопатичні лікарські засоби” для студентів Запорізького державного медичного університету. Обговорюється проблематика медичного та гомеопатичного дискурсів.
\end{abstract}

The article deals with the experience of teaching the course by choice "Homeopathic medicines" for students of Zaporizhian State Medical University. We discuss the issues of medical and homeopathic discourses.

Вступ. У даний час у педагогіці відчувається брак теоретичних знань. Необхідно сконцентрувати свої зусилля на освіту, бо саме вона робить 3 людини особистість. В ході процесу демократизації медицина і культура не повинні відставати від політики й економіки. У такому контексті навчання і освіта стають найбільш масштабними і значущими видами діяльності протягом усього життя.

Зараз перед медициною стоять ті ж завдання, які намагався вирішити засновник гомеопатії Самуїл Ганеман - “лікувати вірно, безпечно, швидко і надійно”. Довгий час алопатична і гомеопатична системи лікування розвивалися самостійно. Кожна з них має безперечні досягнення і недоліки. Здоров'я і хвороба часто визначаються один щодо одного. Здоровий в одному зі своїх значень - це не хворий, а хворий - нездоровий. Здоров'я - нормальний стан правильно функціонуючого, неушкодженого організму, а хвороба - ухилення від норми, розлад.

За останні 15 років на фармацевтичному ринку України з'явилася велика кількість гомеопатичних ліків, як іноземного, так і вітчизняного виробництва. А відповідно і збільшилася частка гомеопатії на ринку. При цьому зростає актуальність як медичного, так і гомеопатичного дискурсів про здоров'я і хвороби.

() А. В. Курінний
Як показує практика, студенти випускного курсу Запорізького державного медичного університету мають уявлення про гомеопатію, але мало знайомі 3 іï принципами і не можуть їх чітко сформулювати. Тому вивчення гомеопатії як наукової дисципліни $€$ актуальним і своєчасним [1, 2].

Основна частина. Гомеопатичні лікарські засоби - дисципліна, яка включена до навчального плану підготовки фахівців за спеціальністю “Фармація” Запорізького державного медичного університету, в якості спеціалізації за вибором, для студентів п’ятого курсу. Викладається на кафедрі технології ліків.

Мета дисципліни - надання студентам теоретичних знань, формування практичних умінь i навиків щодо основних принципів технології гомеопатичних лікарських засобів, потенціювання, особливостей розведень, дозування та відпуску гомеопатичних ліків.

У процесі навчання студенти повинні вивчити особливості приготування гомеопатичних засобів, нормування умов виготовлення, виробництва та якості ліків гомеопатичної медицини. Студенти повинні знати: роль (місце) гомеопатії в сучасній медицині; хімічний склад, діючі речовини, механізми дії гомеопатичних засобів і сучасні методи контролю гомеопатичних засобів.

Навчитися користуватися гомеопатичною фармакопеєю Вільмара Швабе “Гомеопатичні лікарські 
засоби”. Знати сучасний стан гомеопатичної допомоги населенню, анти-гомеотоксичні лікарські засоби, теорію Г. Г. Реккевега. У результаті вивчення навчальної дисципліни студент повинен вміти: користуватися нормативними документами та довідковою літературою щодо властивостей та специфікації компонентів гомеопатичних препаратів; проводити розрахунки мас базових субстанцій та допоміжних речовин для приготування відповідних розведень; прогнозувати взаємодію гомеопатичних препаратів при комбінованому використанні; виписувати рецепти на гомеопатичні засоби і виготовляти гомеопатичні засоби в різних лікарських формах.

Навчальний курс включає в себе 72 години, з яких 4 години лекцій, 36 годин практичних занять та 32 години на самостійну роботу.

Раніше гомеопатія викладалась у лекційному курсі для студентів другого курсу, як курс за вибором. Але, як показує практика, дисципліна краще засвоюється не на перших курсах, а на випускному. Це пояснюється тим, що студенти вже пройшли більшу частину дисциплін по технології ліків та курс філософії і на виході ми маємо практично готових спеціалістів. Студенти випускних курсів також мають деякий практичний досвід після проходження повного курсу навчально-виробничої практики в аптеці, а деякі вже працюють в аптеці у нічну зміну. Таким чином інтерес до дисципліни є і існує мотиваційний принцип. Великий інтерес до дисципліни проявляють також і студенти заочного відділення. Це пояснюється тим, що у фармацевтичній та лікувальній практиці алопатична і гомеопатична системи існують, взаємно збагачуючи одна одну. Росте попит на гомеопатію.

Перед початком викладання основної частини дисципліни треба сформувати різницю між поняттями алопатії і гомеопатії [3].

Алопатія бере за основу казуальний характер розвитку захворювання - спрямована на усунення причин захворювання та його клінічних проявів. А лікування конкретного захворювання по суті полягає в дії на уражену систему або орган з усіма притаманними їм морфологічними або функціональними змінами. При цьому методи впливу на конституційно-особистісні ознаки хворого полягають у додаткових радах про режим поведінки і заходах психотерапевтичного впливу (призначення психотропних, седативних та інших препаратів для пом'якшення аномальної реакції хворого) [4].

3 точки зору медичного дискурсу, до достоїнств алопатії насамперед належить раціональне пояс- нення захворювання, можливість виробити стратегію лікування. Традиційна медицина дає можливість широко використовувати не тільки наукові знання, але й технічні, як засіб лікування (протезування). Але істотним недоліком алопатії є побічна дія, викликана прийомом традиційних ліків або неправильним лікуванням.

На цьому етапі починаємо знайомити студентів із гомеопатією. Гомеопатія - регулююча терапія, метод “викорінення хвороби”, а не усунення їі окремих симптомів, м’яка, без побічної дії корекція захисно-пристосувальних механізмів, яка за допомогою надзвичайно малих доз ліків, призначених за законом подібності, приводить до досить швидкого і надійного результату.

На відміну від алопатії, в якій запорукою правильної терапії $є$ виявлення характеру розвитку захворювання і особливості його патогенезу, гомеопатія розглядає в першу чергу конституціональні ознаки і реакції хворої людини. Симптоми захворювання являють собою реакції організму, спрямовані на лікування. А сам процес лікування полягає у витісненні хвороби з організму за рахунок його активації. Гомеопатія не придушує симптоми, а сприяє процесу одужання. Гомеопатичне лікування спрямоване не на етіологію та патогенез захворювання, а на сукупність властивостей хворого, які визначають індивідуальність його організму. Таким чином, лікування орієнтоване на індивідуального хворого і інтерес представляє діагноз хворого, а не його хвороби [4].

Гомеопатичні засоби добре поєднуються з сучасними фармакологічними засобами і мають успіх, коли не допомагають методи клінічної медицини. 3 точки зору гомеопатичного дискурсу, недоліком гомеопатії є непрозорість (в плані розуміння) природи хвороби і зцілення. Але все стає на свої місця після вивчення основних принципів гомеопатії.

Висновки: 1. За останні 15 років на фармацевтичному ринку України з'явилася велика кількість гомеопатичних ліків, тому вивчення гомеопатії як наукової дисципліни є актуальним і своєчасним.

2. Дисципліну треба викладати студентам старших курсів, які вже мають теоретичний, практичний досвід і існує мотиваційний принцип.

3. Перед початком викладання основної частини дисципліни треба сформувати різницю між поняттями алопатії і гомеопатії, розкриваючи поняття в теоретичному і філософському дискурсі. 


\section{Список літератури}

1. Розин В. М. Философия образований. Этюдыисследования / В. М. Розин. - М. : Изд-во Московского психолого-социального института; Воронеж : Изд-во НПО “МОДЭК”, 2007. - 576 с.

2. Жадько В. А. Формування громадської свідомості: соціальний аналіз / В. А. Жадько, П. О. Бідзіля. - Запоріжжя : ЗДМУ, 2013. - 75 с.
3. Sabitha Marican. Knowledge and intent to know about Complementary and Alternative Medicine Among students in Institutions of Higher Learning in Malaysia / Marican Sabitha, Nazar Mohamed Mahmood // International journal of Homeopathy research. - August 2014. - Vol. 1, No. 1. P. 16-24.

4. Основы гомеопатической фармации / [А. И. Тихонов, С. А. Тихонова, Т. Г. Ярных и др.]. - Х. : Изд-во НФАУ “Золотые страницы”, 2002. - 574 с.

Отримано 20.05.15 